\title{
Factors Associated with Pasung (Seclusion and Restraint) in Indonesia: A Systematic Review
}

\author{
${ }^{1}$ Shofi Khaqul Ilmy, ${ }^{2}$ Noorhamdani, ${ }^{3}$ Heni Dwi Windarwati \\ ${ }^{1,3}$ Department of Mental Health Nursing, Faculty of Medicine, Universitas Brawijaya, \\ Malang, Indonesia \\ ${ }^{2}$ Faculty of Medicine, Universitas Brawijaya, Malang, Indonesia \\ Email: shofi.khaqulilmy@gmail.com
}

\begin{abstract}
Schizophrenia is a chronic and multifactorial mental health problem that occurs in developing countries, including in Indonesia. Families with schizophrenia patients will feel the burden of care and lead to pasung, and supported by various factors. Pasung, by the family, aims to control the aggressive behavior of the patient. A systematic review was conducted by searching four online databases, namely ProQuest, Science Direct, and EBSCO, and Google Scholar in the past ten years. This analysis uses the PRISMA 2009 method and obtained 14 articles for final review. The results obtained are the internal factors that most influence on pasung is the aggressive behavior of schizophrenia patients, both towards themselves, family, or the environment. In comparison, the most influential external factor is the emergence of stigma against patients and their families. Both of these factors cause the family to decide to pasung on schizophrenia patients, associated with feelings of helplessness and hopelessness. Community mental health nursing (CMHN) plays a role in handling and preventing pasung, which must be supported by the government and the community. Increased knowledge about schizophrenia and pasung in community has an impact on improving the mental health status of the community. Optimal mental health is the right of everyone throughout the world, including in Indonesia.
\end{abstract}

Keywords: Family Caregiver, Factor Related Pasung, Schizophrenia, Systematic Review.

\section{A. INTRODUCTION}

Pasung in schizophrenia patients is one of the mental health issues in developing countries, including in Indonesia. Pasung is a term that refers to seclusion and restrains specifically used in Indonesia (WHO, 2019). The prevalence of pasung cases in schizophrenia patients in Indonesia is estimated to be high (Widodo, Prabandari, Sudiyanto, \& Rahmat, 2019). The estimated number of pasung cases in Indonesia reaches 20,000 to 30,000 cases (Lestari \& Wardhani, 2014). According to the Indonesian Basic Health Research (Riskesdas) in 2018, the proportion of households that have schizophrenia patients who have ever been pasung reaches $14.0 \%$ of the total prevalence of schizophrenia (reaching 6.7 per mile). Pasung cases mostly occur in rural areas by $17.7 \%$ (Ministry of Health of the Republic of Indonesia, 2018). Nationally, the estimated calculation of pasung in Indonesia is around 81,300 cases. Pasung is a complex mental health problem because it concerns all levels of society from various sectors, such as the government, health workers, community leaders, and also families with schizophrenia patients. 
Schizophrenia is a severe psychiatric disorder, associated with decreased social functioning and independence, and has the potential to carry out dangerous behaviors for patients and families during their lifetime (Van Os \& Kapur, 2009). Families who provide care for schizophrenia patients are at risk of feeling the burden and result in decreased health status. Some consequences of family burdens, such as mental health problems (for example, depression, anxiety, stress, and fatigue syndrome), decreased physical health (for example, diabetes), and other adverse effects (for example, family dysfunction, social isolation, use excessive health services, and financial problems) (Souza et al., 2017). We think that this condition is the basic reason for families to do pasung, even after handling pasung (re-pasung). According to Puteh, Marthoenis, and Minas (2011), mentioning that the act of retirement had initially received help at the mental hospital, but it did not continue due to economic limitations so that it returned to the situation by the family. This is, of course, very alarming, considering the symptoms can largely be overcome by adequate treatment. The inadequate treatment has caused high cases of pasung in Indonesia.

The phenomena of pasung in Indonesia cannot yet be explained clearly and comprehensively because pasung is a multifactorial phenomenon, both internal and external, of families with schizophrenia patients. Research on pasung in Indonesia is still limited, and handling pasung in the community is not optimal. Overall handling of pasung requires a basis of relevant and up-to-date information about the current pasung situation. This review was developed to collect research results systematically to facilitate the reader in understanding the factors that cause pasung in Indonesia. This review aims to identify the factors that influence pasung in schizophrenia patients in Indonesia.

\section{B. METHOD}

\section{Database Search Process}

Following the objectives of the study, we compiled this review using a systematic approach (systematic review) conducted to find out various factors that influenced family doing pasung in Indonesia. We searched four databases in compiling this review, namely ProQuest, Science Direct, EBSCOhost, and Google Scholar. Search in this review was limited by using several keywords, namely "factor" AND "pasung" OR "seclusion" OR "restraint" AND "confinement" AND "schizophrenia". Research articles have been traced in both English and Indonesian in the past ten years. This step was carried out in each database.

\section{Search Analysis and Criteria}

We used the Preferred Reporting Item for Systematic Review and MetaAnalysis (PRISMA) 2009 approach to analyze various articles obtained from the database. To achieve the research objectives, analysis of search results in the database was done by using the inclusion and exclusion criteria used in filtering literature search results. Inclusion criteria used in this review include: 1) The study 
subjects were schizophrenia patients and their families; 2) Family who do pasung in schizophrenia patients; 3) Done in community settings; 4) Research was carried out in Indonesia; 5) Articles published in Indonesian journals, at least indexed by SINTA 2. Exclusion criteria used include 1) Traditional literature review articles; 2) Only in the form of abstracts and other forms of writing (poster presentation, award, or oral presentation); 3) Published more than ten years ago.

\section{Article Selection and Data Extraction}

Selected articles for extraction were selected based on the quality of the articles. The quality of research articles was assessed using JBI. Critical Appraisal Tools with minimum criteria of $60 \%$ by two authors. The author will critically evaluate articles. Articles of uncertain quality will be assessed by other authors to determine inclusion in this systematic review. Analysis carried out in accordance with figure 1, produced 11 articles which will then be discussed. The relevant article will be summarized in table 1 .

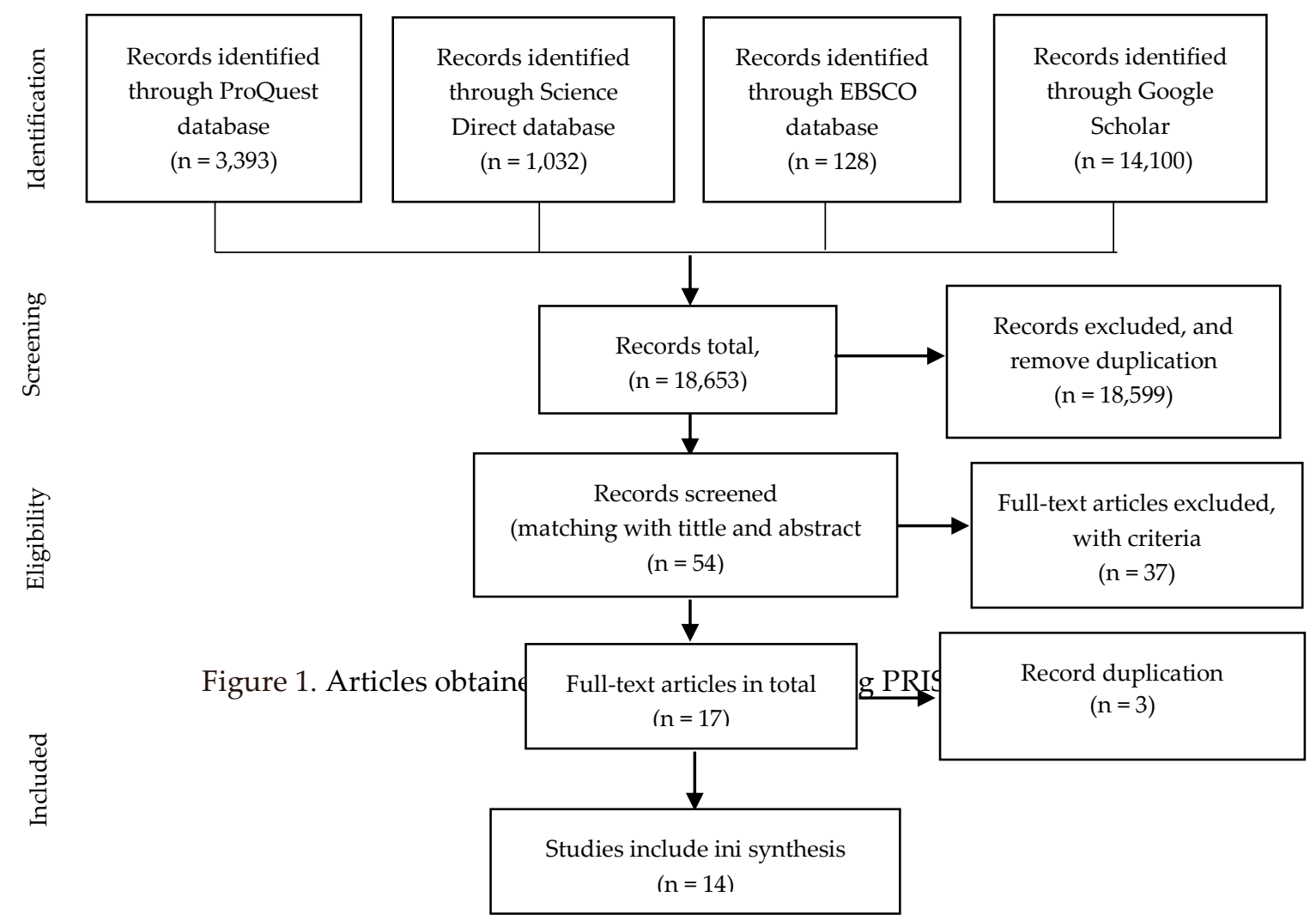


Table 1. Summary of Articles on Systematic Search Results

\begin{tabular}{|c|c|c|c|c|c|c|c|c|c|c|c|c|c|c|c|c|c|}
\hline \multirow[b]{2}{*}{ No } & \multirow[b]{2}{*}{$\begin{array}{l}\text { Author } \\
\text { (Year) }\end{array}$} & \multirow[b]{2}{*}{ Design } & \multicolumn{3}{|c|}{ Characteristic of patient } & \multirow[b]{2}{*}{$\begin{array}{l}\text { Dura- } \\
\text { tion of } \\
\text { pasung }\end{array}$} & \multicolumn{7}{|c|}{ Internal Factor } & \multicolumn{4}{|c|}{ External Factor } \\
\hline & & & Gender & $\begin{array}{c}\text { Age } \\
\text { (years) }\end{array}$ & $\begin{array}{l}\text { Edu- } \\
\text { cation }\end{array}$ & & $\begin{array}{l}\text { Aggre- } \\
\text { ssive } \\
\text { beha- } \\
\text { vior }\end{array}$ & $\begin{array}{l}\text { Patient } \\
\text { Wande- } \\
\text { ring }\end{array}$ & $\begin{array}{l}\text { Relap- } \\
\text { se }\end{array}$ & $\begin{array}{l}\text { Dura- } \\
\text { tion of } \\
\text { illness }\end{array}$ & $\begin{array}{l}\text { Lack of } \\
\text { know- } \\
\text { ledge }\end{array}$ & $\begin{array}{c}\text { Low } \\
\text { family } \\
\text { edu- } \\
\text { cation }\end{array}$ & $\begin{array}{l}\text { Finan } \\
\text {-cial } \\
\text { issues }\end{array}$ & $\begin{array}{l}\text { Dissatis- } \\
\text { faction } \\
\text { of } \\
\text { Health } \\
\text { care } \\
\end{array}$ & Stigma & $\begin{array}{l}\text { Social } \\
\text { support }\end{array}$ & $\begin{array}{l}\text { Pasung } \\
\text { as the } \\
\text { accepted } \\
\text { norm }\end{array}$ \\
\hline 1 & $\begin{array}{l}\text { Puteh el al. } \\
\text { (2011) }\end{array}$ & $\begin{array}{l}\text { Cross- } \\
\text { sectional } \\
\text { descriptive } \\
\text { study }\end{array}$ & Male & $\begin{array}{l}18- \\
68\end{array}$ & Low & $\begin{array}{l}\text { A few } \\
\text { days - } \\
20 \text { years }\end{array}$ & $\sqrt{ }$ & & & $\sqrt{ }$ & & & $\sqrt{ }$ & & & & \\
\hline 2 & $\begin{array}{l}\text { Suryani et } \\
\text { al. (2011) }\end{array}$ & $\begin{array}{l}\text { Epidemi- } \\
\text { ological } \\
\text { population } \\
\text { survey }\end{array}$ & Male & $19-69$ & $\mathrm{n} / \mathrm{a}$ & $\begin{array}{l}3 \\
\text { months } \\
-30 \\
\text { years }\end{array}$ & & & & & $\sqrt{ }$ & $\sqrt{ }$ & & & & & \\
\hline 3 & $\begin{array}{l}\text { Nihayati et } \\
\text { al. (2016) }\end{array}$ & $\begin{array}{l}\text { Phenome- } \\
\text { nological } \\
\text { study }\end{array}$ & $\mathrm{n} / \mathrm{a}$ & $\mathrm{n} / \mathrm{a}$ & $\mathrm{n} / \mathrm{a}$ & $\mathrm{n} / \mathrm{a}$ & $\sqrt{ }$ & $\sqrt{ }$ & & & & & $\sqrt{ }$ & & & & \\
\hline 5 & $\begin{array}{l}\text { Astuti } \\
\text { (2017) }\end{array}$ & $\begin{array}{l}\text { Convergent } \\
\text { parallel } \\
\text { mixed } \\
\text { methodes }\end{array}$ & $\mathrm{n} / \mathrm{a}$ & $19-54$ & Low & $\mathrm{n} / \mathrm{a}$ & $\sqrt{ }$ & & $\sqrt{ }$ & $\sqrt{ }$ & $\sqrt{ }$ & $\sqrt{ }$ & $\sqrt{ }$ & & & $\sqrt{ }$ & \\
\hline 6 & $\begin{array}{l}\text { Yusuf et al. } \\
\text { (2017) }\end{array}$ & $\begin{array}{l}\text { Phenome- } \\
\text { nological } \\
\text { study }\end{array}$ & $\mathrm{n} / \mathrm{a}$ & $\mathrm{n} / \mathrm{a}$ & Low & $\begin{array}{l}7 \text { days }- \\
24 \text { years }\end{array}$ & $\sqrt{ }$ & $\sqrt{ }$ & & $\sqrt{ }$ & $\sqrt{ }$ & $\sqrt{ }$ & & & & & \\
\hline 7 & $\begin{array}{l}\text { Buanasari } \\
\text { et al. } \\
(2018)\end{array}$ & $\begin{array}{l}\text { Phenome- } \\
\text { nological } \\
\text { study }\end{array}$ & $\mathrm{n} / \mathrm{a}$ & $\mathrm{n} / \mathrm{a}$ & $\mathrm{n} / \mathrm{a}$ & $\mathrm{n} / \mathrm{a}$ & & & & & & $\sqrt{ }$ & & & $\sqrt{ }$ & & \\
\hline
\end{tabular}




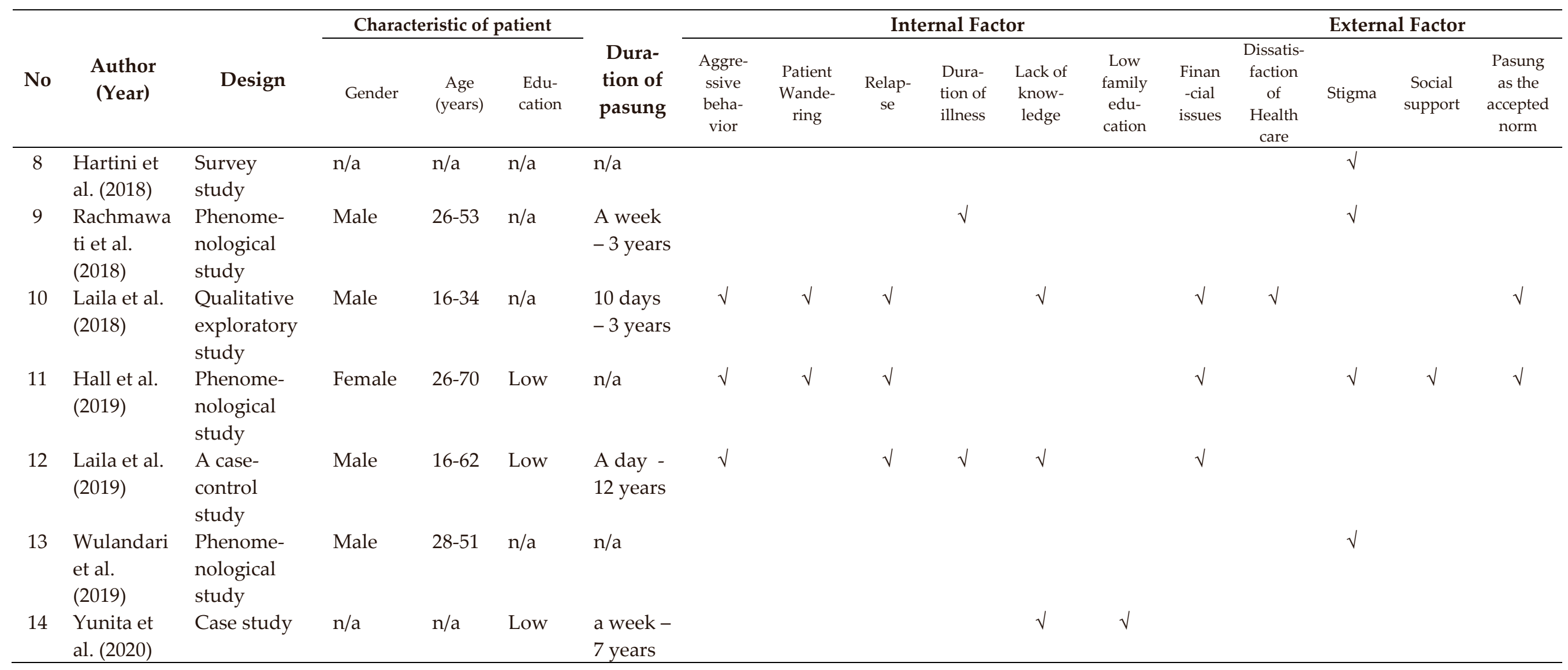




\section{RESULT AND DISCUSSION}

Preliminary search results obtained 3,393, 1,032, 128, and 14,100 articles from ProQuest, Science Direct, EBSCO, and Google Scholar, respectively. Based on the review of the title and abstract, from ProQuest, Science Direct, EBSCO, and Google Scholar were obtained 13, 16, 9, and 27, respectively. Of the 54 articles, each was read in full or in full text. Thirty-seven articles were excluded because they did not fit the researchers' inclusion criteria and three duplicate articles. Then, there were 14 articles to be analyzed.

Based on table 1, the study was conducted on people with severe mental disorders in the age range of 16-70 years, the majority of men, and low education. The duration of pasung in schizophrenia patients varies, starting from 1 day to 30 years. Based on internal factors of families with schizophrenia patients in pasung, the majority of articles mention about aggressive behavior of patient by eight articles $(57.1 \%)$, on other factors such as patient wandering, relapse, duration of illness, lack of knowledge, low family education, and financial issues found $4(28.6 \%), 4(28.6 \%)$, $5(35.7 \%), 6(42.9 \%), 5(35.7 \%)$, and $6(42.9 \%)$ articles respectively. While the external factors in pasung actions by the family, obtained the most factors are the stigma of 6 articles $(42.9 \%)$, while the dissatisfaction of mental health care system factors, social support and preception of pasung as the accepted norm in community obtained 1 $(7.0 \%), 2(14.3 \%)$, and $2(14.3 \%)$ articles respectively.

Based on a systematic review carried out, we will describe the factors that affect pasung in schizophrenia patients who will be divided into family internal factors and family external factors, which will be described as follows:

\section{Family internal factors due to pasung}

The results of the review found that three internal family factors influence the pasung action, including (1) Aggressive and destructive behavior of schizophrenia patients (Astuti, 2017; Hall et al., 2019; Laila, Mahkota, Krianto, \& Shivalli, 2018; Laila, Mahkota, Shivalli, Bantas, \& Krianto, 2019; Nihayati, Mukhalladah, \& Krisnana, 2016; Puteh et al., 2011; Subu, Holmes, \& Elliot, 2016; Yusuf, Tristiana, \& Purwo, 2017); (2) Lack of knowledge about schizophrenia and pasung (Astuti, 2017; Laila et al., 2018; Laila et al., 2019; Suryani, Lesmana, \& Tiliopoulos, 2011; Yunita, Yusuf, Nihayati, \& Hilfida, 2019; Yusuf et al., 2017); and (3) Financial issues (Astuti, 2017; Hall et al., 2019; Laila et al., 2018; Laila et al., 2019; Nihayati et al., 2016; Puteh et al., 2011). The aggressive behavior of schizophrenia patients is seen as disturbing because the schizophrenia patient can harm others and damage the surrounding environment. Laila et al. (2019) mentioned factors of aggressive behavior or violent behavior, causing concerns about patients wandering or running away, the possibility of suicide, and no supervision from family. The issue of financial difficulties due to poverty and unemployment in the family or both may be the root causes of pasung. Hall et al. (2019) stated that families experience financial difficulties when their family breadwinner is unable to work due to poor health. 


\section{Family External Factors Due to Pasung}

Most external factors are mentioned that affect pasung, including stigma (Buanasari, Daulima, \& Wardani, 2018; Hall et al., 2019; Hartini, Fardana, Ariana, \& Wardana, 2018; Rasmawati, Daulima, \& Wardani, 2018; Subu et al., 2016; Wulandari, Daulima, \& Wardani, 2019), and pasung is considered the accepted norm in the community (Hall et al., 2019; Laila et al., 2018). Wulandari et al. (2019) mentioned that the stigma experienced by schizophrenia patients could have negative effects on social and cultural attitudes, such as a wrong understanding of the mental illness. The difference in opinion can create negative perceptions of mental illness patients, which will lead to pasung practice. According to Hall et al. (2019), pasung is considered an accepted norm, the community thinks that it is better to let people with mental illness stay inside for the rest of their lives. Because they believe that if they let go, they might cause problems in the community.

Schizophrenia is related to the decline in the function of fulfilling daily needs and social functions and is even considered dangerous for oneself, family, or even the surrounding environment. The role of the family as primary caregivers is often overwhelmed by the behavior of schizophrenia patients (Mantovani et al., 2016). Research conducted by Sharma, Sharma, and Pradhan (2017) states that $72 \%$ of families have high-stress levels, 25\% experience depression, and 29\% experience anxiety related to the treatment of schizophrenia patients. Some of the effects of the burden of care include mental health problems (e.g., depression, anxiety, stress, and fatigue), decreased physical health (e.g., increased blood pressure and diabetes), and other negative effects (e.g., family dysfunction, social isolation, use of health services overuse, and financial problems) (Souza et al., 2017). Mantovani et al. (2016) stated that different levels of burden could be found throughout the families, depending on the patient, caregiver, or environmental features. Previous studies found that the level of disability, symptoms that appear, and the sex of the patient affected the family burden. Among caregivers, coping skills, level of education, and relationships with patients (e.g., being parents) contribute to a significant difference in the burden of family care, which leads to pasung.

Pasung decisions about people with mental illness are made after family discussions. Pasung is performed when the family experiences stressors of aggressive client behavior, financial issues, failure of the therapeutic regimen, lack of knowledge, and dissatisfaction with health services (Eka \& Daulima, 2019). These experiences are factors that influence family decisions, whether from internal or external families with schizophrenia patients. We argue that the family discussion that occurs arises because of feelings of sadness, worry, hopelessness, and helplessness, related to the severity of the disease and long-term care (found to have a maximum duration of 30 years). If we associate it with the Kubler-Ross (1998), the model of the five stages of grieving, family, and pasung discussions are carried out, including the stages of "bargaining" and "depression". At stage bargaining, the family has difficulty finding the meaning of the illness they are experiencing, and the family is seeking help and telling others. In the depression stage the family feels 
overwhelmed in caring for feeling helpless, hostile, and wants to get out of the problem that occurred.

The factors found in this review can be used as a basis for conducting the assessment. Based on the "Stress Adaptation Model" by Stuart (2013), the factors obtained are categorized as predisposing factors (defined as factors that occur more than six months) and precipitating factors (identified as factors that occur in less than six months), both assessment factors in schizophrenia patients or families. In schizophrenia patients, duration of illness and relapse are included in predisposing biological factors. At the same time, factors of lack of knowledge about the illness, low education, financial issues, dissatisfaction with health services, social support, and pasung as accepted norms are predisposing factors to the socio-culture of family. In contrast, aggressive/destructive behavior of patients, wandering patients, and stigma that occurs is a precipitating factor of family. We argue that pasung is a form of coping mechanism that occurs due to factors experienced. Coping mechanisms performed by families can be classified as constructive or destructive coping mechanisms.

In this review, the authors review several studies related to pasung in schizophrenia patients. Information about factors related to pasung is useful to improve the handling of pasung comprehensively. Community Mental Health Nursing (CMHN) has an important role in identifying family factors for pasung in schizophrenia patients, especially during the COVID-19 pandemic. Mental health nurses can conduct early detection activities, handling mental illness of patients, family counseling, and mental health promotion in the community to be able to manage risk factors for pasung, pasung impact, and increase public knowledge about mental health. These activities are carried out to boost physical immunity and mental immunity in preventing the deterioration of the mental health of patients and families because there is a risk of mental health decline during the COVID-19 pandemic, related to the physical distancing protocol.

There are limitations in the preparation of this review, which is a limited article about pasung in Indonesia based on an international database, so researchers also use a research database in Indonesia to support tracking following the purpose of the review. Besides, there is a recent study of pasung in Indonesia that is not accessible to researchers. The author suggests that it is important to research pasung with various approaches, one of which is a qualitative approach, related to family experiences in treating schizophrenia patients in pasung and mental health service factors that influence pasung from the perspective of health workers.

\section{CONCLUSIONS}

The community still considers pasung as a step that needs to be taken to protect patients with schizophrenia and the environment from dangerous patient behavior, even protect patients from physical and sexual violence that occurs outside of family supervision. Individuals with schizophrenia are one of the populations that are vulnerable to COVID-19 in the community, so we have to support and protect 
schizophrenia patients as part of the community. Pasung is multifactorial, both from internal families or communities. The results of the review stated that many factors affect the situation in schizophrenia patients performed by families. Improving mental health services, especially in rural areas and emphasizing accessibility and quality, is very important to be carried out by the government in realizing the mental health of the Indonesian people. A healthy mind is the right of all Indonesian people, regardless of economic status, ethnicity, religion, or race. This was realized in accordance with the mandate stated in the Law of the Republic of Indonesia No. 18 of 2014 concerning mental health.

\section{ACKNOWLEDGEMENT}

We would like to express gratitude to the Master of Nursing Program, School of Nursing, Universitas Brawijaya. We also thank Prof. Dr. Titin Andri Wihastuti, S.Kp., M.Kes. and Dr. Yati Sri Hayati S.Kp., M.Kes., who have provided suggestions for the study. The review compiled is part of further research on pasung in schizophrenia patients. The results are used in support of theoretical studies in conducting the research.

\section{REFERENCES}

1. Astuti, M. (2017). Kondisi orang dengan gangguan jiwa pasung, keluarga dan masyarakat lingkungannya di Kabupaten 50 Kota. Sosio Konsepsia: Jurnal Penelitian dan Pengembangan Kesejahteraan Sosial, 6(3), 256-268. doi: 10.33007/ska.v6i3.1000

2. Buanasari, A., Daulima, N.H.C., \& Wardani, I.Y. (2018). The experience of adolescents having mentally ill parents with pasung. Enfermería Clínica, 28(Supl 1 Part A), 83-87. doi: 10.1016/S1130-8621(18)30043-3

3. Eka, A.R., \& Daulima, N.H.C. (2019). Factors related to pasung on people with mental illness: A literature review. International Journal of Nursing and Health Services, 2(2), 36-41.

4. Hall, T., Kakuma, R., Palmer, L., Minas, H., Martins, J., \& Kermode, M. (2019). Social inclusion and exclusion of people with mental illness in Timor-Leste: a qualitative investigation with multiple stakeholders. BMC. Public Health, 19:702. doi: 10.1186/s12889-019-7042-4

5. Hartini, N., Fardana, N.A., Ariana, A.D., \& Wardana, N.D. (2018). Stigma toward people with mental health problems in Indonesia. Psychology Research and Behavior Management, 11, 535-541. doi: 10.2147/PRBM.S175251

6. Kubler-Ross, E. (1998). Kematian sebagai kehidupan: On death and dying. Jakarta: Gramedia Pustaka Utama.

7. Laila, N.H., Mahkota, R., Krianto, T., \& Shivalli, S. (2018). Preception about pasung (physical restraint and confinement) of schizophrenia patients: A qualitative study among family members and other key stakeholders in Bogor Regency, West Java Province, Indonesia 2017. International Journal of Mental Health System, 12(35), 1-7. doi: 10.1186/s13033-018-0216-0 
8. Laila, N.H., Mahkota, R., Shivalli, S., Bantas, K., \& Krianto, T. (2019). Factors associated with pasung (physical restraint and confinement) of schizophrenia patients in Bogor regency, West Java Province, Indonesia 2017. BMC. Psychiatry, 19(162), 1-8. doi: 10.1186/s12888-019-2138-z

9. Lestari, W., \& Wardhani, Y.F. (2014). Stigma and handling of people with severe mental disorders in pasung. Buletin Penelitian Sistem Kesehatan, 17(2), 157-166.

10. Mantovani, L.M., Ferretjans, R., Marçal, I.M., Oliveira, A.M., Guimarães, F.C., \& Salgado, J.V. (2016). Family burden in schizophrenia: The influence of age of onset and negative symptoms. Trends Psychiatry Psychother, 38(2), 96-99. doi: 10.1590/2237-6089-2015-0082

11. Ministry of Health of the Republic of Indonesia. (2018). National report of Basic Health Research 2018. Jakarta: Ministry of Health of the Republic of Indonesia.

12. Nihayati, H.E., Mukhalladah, D.A., \& Krisnana, I. (2016). Pengalaman keluarga merawat klien gangguan jiwa pasca pasung. Jurnal Ners, 11(2), 283-287. doi: 10.20473/jn.v11i2.2988

13. Puteh, I., Marthoenis, M., \& Minas, H. (2011). Aceh Free Pasung: Releasing the mentally ill from physical restraint. Imternational Journal of Mental Health Systems, 5(10), 1-5. doi: 10.1186/1752-4458-5-10

14. Rasmawati, Daulima, N.H.C., \& Wardani, I.Y. (2018). The experience of people with mental disorders in social function adaptation after suffering from pasung. Enfermería Clínica, 28(Supl 1 Part B), 275-279. doi: https://doi.org/10.1016/S11308621(18)30169-4

15. Sharma, R., Sharma, S.C., \& Pradhan, S.N. (2017). Assessing caregiver burden in caregivers of patients with schizophrenia and bipolar affective disorder in Kathmandu Medical College. J Nepal Health Res Counc, 15(37), 258-263. doi: 10.3126/jnhrc.v15i3.18851

16. Souza, A.L.R., Guimarães, R.A., Vilela, D.D.A., Assis, R.M.D, Oliveira, LMDAC, Souza, M.R., . . . Barbosa, M.A. (2017). Factors associated with the burden of family caregivers of patients with mental disorders: a cross-sectional study. BMC Psychiatry, 17(353), 1-10. doi: 10.1186/s12888-017-1501-1

17. Stuart, G.W. (2013). Principles and practice psyciatric nursing (10 ${ }^{\text {th }}$ ed.). St. Louis, Mo.: Elsevier.

18. Subu, M.A., Holmes, D., \& Elliot, J. (2016). Stigmatisasi dan perilaku kekerasan pada orang dengan gangguan jiwa (ODGJ) di Indonesia. Jurnal Keperawatan Indonesia, 19(3), 191-199. doi: 10.7454/jki.v19i3.481

19. Suryani, L.K., Lesmana, C.B.J., \& Tiliopoulos, N. (2011). Treating the untreated: applying a community-based, culturally sensitive psychiatric intervention to confined and physically restrained mentally ill individuals in Bali, Indonesia. Eur Arch Psychiatry Clin Neurosci, 261(Suppl 2), S140-S144.

20. Van Os, J., \& Kapur, S. (2009). Schizophrenia. Lancet, 374(9690), 635-645. doi: 10.1016/S0140-6736(09)60995-8

21. WHO. (2019). Strategies to end seclusion and restraint (Course guide). Geneva: WHO QualityRights Specialized training. 
22. Widodo, A., Prabandari, Y.S., Sudiyanto, A., \& Rahmat, I. (2019). Increasing the quality of life of post-shackling patients through multilevel Health promotion of shackling prevention. Bali Medical Journal, 8(2), 542-549.

23. Wulandari, I.A.P., Daulima, N.H.C., \& Wardani, I.Y. (2019). The fight against stigma in the recovery process of post-pasung mentally ill patients. Enfermería Clínica, 29(S2), 295-299. doi: 10.1016/j.enfcli.2019.04.037

24. Yunita, F.C., Yusuf, A., Nihayati, H.E., \& Hilfida, N.H. (2019). Coping strategies used by families in Indonesia when caring for patients with mental disorders post-pasung, based on a case study approach. General Psychiatry, 33:e100035. doi: 10.1136/gpsych-2018-100035

25. Yusuf, A., Tristiana, R.D., \& Purwo, I. (2017). Fenomena pasung dan dukungan keluarga terhadap pasien gangguan jiwa pasca pasung. Jurnal Keperawatan Padjajaran, 5(3), 302-314. doi: 10.24198/jkp.v5i3.653 